\title{
PENGARUH PESAN POLITIK CALEG PKS MELALUI LAYANAN PESAN SINGKAT (SMS) TERHADAP SIKAP DAN PERILAKU PEMILIH DALAM PEMILU LEGISLATIF 2009 DI KOTA MAKASSAR
}

\author{
Arifuddin \\ Peneliti Pertama Balai Besar Pengkajian dan Pengembangan Komunikasi dan Informatika Makassar \\ (Naskah diterima 22 Desember 2010 - Revisi 31 Maret 2011)
}

\begin{abstract}
Abstrak
Dalam konteks politik, telepon seluler ternyata bisa menjadi sarana komunikasi politik yang cukup efektif dalam menggalang kerja sama dan percepatan mobilitas organisasi dan partai. Melalui SMS orang memiliki kebebasan untuk mengembangkan issue dan gosip yang menyudutkan orang lain. Dalam pemilu, telepon seluler banyak digunakan untuk menyebar luaskan pesan yang bersifat menolak, mengejek, mendukung, merongrong, dan menyindir seorang kandidat.Tujuan penelitian ini adalah untuk (1) Untuk menganalisis bentuk pesan politik caleg PKS melalui SMS Layanan Pesan Singkat (SMS) terhadap pemilih dalam pemilu legislatif 2009 di Kota Makassar. (2) Untuk menganalisis pengaruh pesan-pesan politik caleg PKS melalui Layanan Pesan Singkat (SMS) terhadap pemilih dalam pemilu legislatif 2009 di Kota Makassar.Jenis penelitian ini adalah kuantitatif. Teknik penarikan sampel yang digunakan dalam penelitian ini adalah nonprobability sampel bertahap dengan jumlah sampel sebesar 263 orang. Data yang telah dikumpulkan, selanjutnya dianalisis dengan menggunakan teknik Analisis Deskriptif Kuantitatif dengan Metode Regresi.

Hasil penelitian menunjukkan bahwa caleg PKS Kota Makassar mempunyai cara yang berbeda dalam mengolah pesan politik melalui SMS yang kemudian dikirim ke pemilih. Ada pesan politik yang bersifat informatif juga ada yang persuasif. Penyusunan pesan tertentu diyakini oleh caleg dapat menarik perhatian pemilih. Semua bentuk pesan politik caleg PKS melalui SMS yang masuk ke handphone pemilih dilakukan untuk satu tujuan yang sama, yaitu, memromosikan dirinya, agar masyarakat dapat terbujuk untuk mengalihkan pilihannya pada caleg tersebut. Hasil penelitian juga menunjukkan bahwa menolak Ho yang berarti kontribusi variabel independen (pesan kampanye caleg melalui SMS) signifikan dalam memrediksi variabel dependen (sikap dan perilaku pemilih Kota Makassar).
\end{abstract}

Kata Kunci : Kampanye Politik, Pesan SMS, Sikap dan Perilaku Pemilih

\section{Abstract}

In a political context, mobile phones could actually be a means of political communication is quite effective in eliciting cooperation and accelerating organizational mobility and SMS partai. People have the freedom to develop the issue and discrediting the gossip of others. In the election, cell phones are widely used to disseminate messages that are rejected, ridiculed, support, undermine, and insinuated a candidate. This research aims to (1) find out the style of the message of legislative Candidates though short message service (SMS) toward voters in 2009 Legislatif Election in Makassar City, and (2) analyze the influence of political message of PKS Legislatif Election in Makassar City. This research was quantitative study. The sample was selected using nonprobability sampling method consisting of 263 people. The data were then analyzed using descriptive quantitative analysis by means of regression method. The results show that PKS Legislatif Candidates of Makassar City have differen styles in processing 
political messages through short message service (SMS) sent to the voters. Some political messages are informative and some others are persuasive. Such styles are believed to interest the voters. All of the political messages sent to the voters' hand phone are intended to promote themselves so that the community is interested in electing them. Besides, the result also indicates that Ho is rejected which means that the contribution of independent variable (campaign messages of legislative candidates through SMS) is significant in predicting the dependent variable (voters' attitude and behavior in Makassar City).

Keywords : political campaign, message of short message service, voters attitude and behavior.

\section{PENDAHULUAN}

Dalam konteks politik, telepon seluler ternyata bisa menjadi sarana komunikasi politik yang cukup efektif dalam menggalang kerja sama dan percepatan mobilitas organisasi dan partai. Di Thailand kalangan kelas menengah berhasil menggalang dan mengajak massa untuk turun ke jalan menolak kudeta militer tahun 1992. Demikian juga di Philipina melalui pesan SMS massa berhasil menggalang kekuatan untuk turun ke jalan menuntut Josep Estrada (Erap) turun sebagai presiden pada tahun 2001. menurut Smart Communication Incorporated, penggunaan SMS selama masa tuntutan penurunan Estrada sebagai presiden meningkat $50 \%$ dari 45 juta sampai 70 juta pesan SMS perhari ( 15 - 21 Januari 2001). Kampanye Barrack Obama untuk menjadi presiden AS 2008 juga banyak menggunakan SMS, termasuk untuk menentukan calon wakil presidennya. Keadaan yang sama juga terjadi di Indonesia penggunaan telepon seluler dengan pengiriman pesan pendek (SMS) mulai gencar ketika ada tuntutan untuk mengimpeach Gus Dur agar berhenti sebagai presiden RI bahkan banyak berita dikirim ke stasiun TV melalui SMS dan disiarkan dalam bentuk running text (Cangara, 2000: 401).

Melalui SMS orang memiliki kebebasan untuk mengembangkan issue dan gosip yang menyudutkan orang lain. Dalam pemilu, telepon seluler banyak digunakan untuk menyebar luaskan pesan yang bersifat menolak, mengejek, mendukung, merongrong, dan menyindir seorang kandidat. Ketika Undang-undang Pemilu Daerah (Pilkada) belum diundangkan, para anggota DPRD yang akan memilih bupati atau walikota harus diisolasi ke hotel atau daerah tertentu yang tidak diperkenankan membawa dan menerima telepon sampai hari H. Hal itu dilakukan oleh partai politik untuk menghindari para wakil-wakilnya terpengaruh dalam pemberian suara. Sampai sejauh mana SMS memengaruhi masyarakat dalam memilih caleg?

Sudah ada wacana bahwa kampanye melalui telepon dan SMS akan diatur dan tampaknya memang akan sulit diatur seperti halnya internet. Tetapi dibalik itu semua pesan-pesan yang dimodifikasi dengan penuh humor menjadi hiburan tersendiri, baik di kalangan politisi maupun di kalangan masyarakat. Misalnya pesan SMS yang dikirim seseorang dengan tulisan "setelah wabah SARS, Flu Burung, Sapi Gila, dan demam berdarah, maka wabah yang membahayakan masyarakat adalah penyakit kuning (Golkar)". Demikian juga ketika sebuah televisi swasta melakukan polling melalui SMS, partai mana yang bakal keluar sebagai pemenang pemilu 2009, ternyata partai paling banyak mendapat dukungan melalui SMS ternyata bukan itu yang menjadi pilihan rakyat. Begitulah SMS, sebuah fenomena baru di kalangan anggota masyarakat dalam berkomunikasi, yakni di satu sisi penuh dengan kecepatan dan transparansi namun di sisi lain penuh dengan kebohongan.

Pakar ilmu komunikasi, Jalaludin Rahmat menyebut metode kampanye berbasis IT dan jarak jauh lewat SMS lebih mirip apa yang dahulu pernah disebut dengan istilah kampanye berbisik "whispering campaign". Dengan biaya SMS yang semakin murah memungkinkan tim sukses tertentu untuk menggalang pengiriman SMS dan SMS 
berantai hingga jutaan SMS. SMS ternyata juga sangat efektif dalam mengingat (memory recall) seorang individu. (http://batampos.co.id).

Demikian pula pada Partai Keadilan Sejahtera (PKS), pesan-pesan politiknya disampaikan melalui melalui media Short Message Service (SMS) atau Layanan pesan singkat atau Surat Masa Singkat yang banyak mendapat respon dari berbagai kalangan, termasuk respons adalah pemilih di Kota Makassar. Dari segi biaya pun, SMS tentu lebih hemat dibanding kampanye melalui media lain. Sebagai sarana komunikasi massa, SMS sifatnya efektif, murah, dan memenuhi kriteria komunikasi massa, yaitu dilaksanakan oleh sebuah institusi, ada unsur keserempakan dan disebarkan ke masyarakat luas.

Berdasarkan uraian tersebut di atas, dapat dikemukakan pertanyaan yang mendasari penelitian ini : Bagaimana bentuk pesan politik calon legislatif Partai Keadilan Sejahtera (PKS) melalui SMS atau Layanan Pesan Singkat terhadap pemilih dalam pemilu legislatif 2009 di kota Makassar?. Bagaimana pengaruh pesan-pesan politik calon legislatif Partai Keadilan Sejahtera (PKS) melalui SMS atau Layanan Pesan Singkat terhadap pemilih dalam pemilu legislatif 2009 di Kota Makassar?

Tujuan penelitian ini adalah pertama untuk menganalisis bentuk pesan politik calon legislatif Partai Keadilan Sejahtera (PKS) melalui SMS atau Layanan Pesan Singkat terhadap pemilih dalam pemilu legislatif 2009 di kota Makassar. Kedua, untuk menganalisis pengaruh pesan-pesan politik calon legislatif Partai Keadilan Sejahtera (PKS) melalui SMS atau Layanan Pesan Singkat terhadap pemilih dalam pemilu legislatif 2009 di Kota Makassar.

\section{LANDASAN KONSEP}

\section{Komunikasi politik}

Gabriel Almond (1960:109) : komunikasi politik adalah salah satu fungsi yang selalu ada dalam setiap sistem politik. "All of the functions performed in the political sys- tem, political socialization and recruitment, interest articulation, interest aggregation, rule making, rule application, and rule adjudication, are performed by means of communication." Komunikasi politik merupakan proses penyampaian pesan-pesan yang terjadi pada saat keenam fungsi lainnya itu dijalankan. Hal ini berarti bahwa fungsi komunikasi politik terdapat secara inherent di dalam setiap fungsi sistem politik.

Menurut McNair (2003) dalam Cangara (2009: 35) menjelaskan bahwa "political communication as pure discussion about the allocation of public resources (revenues), official authority (who is given the power to make legal, legislatif and executive decision), and official sanctions (what the state reward or punishes). "Jadi komunikasi politik menurut McNair adalah murni membicarakan tentang alokasi sumberdaya publik yang memiliki nilai, apakah nilai itu kekuasaan atau nilai ekonomi, petugas yang memiliki kewenangan untuk memberi kekuasaan dan keputusan dalam pembuatan undang-undang atau aturan, apakah itu legislatif atau eksekutif, serta sangsi-sangsi, apakah itu dalam bentuk hadiah atau denda. Untuk menghindari kajian komunikasi politik itu tidak hanya bicara kekuasaan, maka Doris Graber (1981: 122) mengingatkan bahwa komunikasi politik tidak hanya retorika tetapi juga mencakup simbol-simbol bahasa, seperti bahasa tubuh serta tindakan-tindakan politik seperti boikot, protes dan unjuk rasa.

\section{Pesan}

Cangara (2007: 24) menjelaskan bahwa pesan adalah sesuatu yang disampaikan pengirim kepada penerima. Pesan dapat disampaikan dengan cara tatap muka atau melalui media komunikasi. Isinya bisa berupa pengetahuan, hiburan, informasi, nasihat atau propaganda. Menurut Cassandra dalam Cangara (2007: 115) bahwa terdapat dua model penyusunan pesan, yakni penyusunan pesan yang besifat informatif dan penyusunan pesan yang bersifat persuasif. 


\section{Short Message Service (SMS)}

SMS pertama diuji coba pada Desember 1992. Pesan itu dikirim dari sebuah Personal Computer ke sebuah telepon seluler dalam jaringan GSM milik operator seluler Vodafone di Inggris. Tak ada yang menyangka bahwa hal itu akan menjadi dasar dari satu aplikasi terpenting komunikasi nirkabel. Nyatanya, selama 13 tahun kemudian, pemanfaatan Short Message Service (SMS) terus melambung. Pesan singkat SMS merupakan bagian dari kemampuan standar GSM fase pertama. Menurut standar itu, satu pesan menampung maksimal 160 karakter untuk huruf Latin dan 70 karakter untuk huruf lainnya, seperti huruf Arab dan China.

Kemampuan pengiriman pesan dua arah, menjadi faktor terpenting yang mendorong perkembangan SMS. Bagi institusi publik, SMS bisa menjadi sarana komunikasi interaktif yang penting. Media massa, kantor pemerintahan, lembaga negara, merupakan institusi publik yang butuh informasi valid dan langsung dari masyarakat. Masyarakat pun akan merasa senang jika keluhan, pendapat, dan pandangannya dapat diketahui dan didengar langsung oleh pihak yang memiliki otoritas.

\section{Kepartaian Di Indonesia}

Pencalonan untuk menduduki jabatan publik dapat dilakukan melalui tiga cara, yakni :

- Kaukus partai, adalah pertemuan yang diadakan oleh pimpinan partai untuk memilih calon yang akan ditempatkan untuk suatu jabatan.
- Konvensi (convention), dilakukan untuk memilih salah satu calon yang akan diusung oleh partai. Bisa dilakukan secara tertutup untuk kalangan internal partai, tetapi bisa juga dilakukan secara terbuka kepada siapa saja yang memenuhi syarat untuk jabatan yang akan diisi, misalnya Presiden atau Gubernur.

- Primary Election, adalah memberi dukungan dan memilih calon yang didominasi oleh partai untuk pemilu, apakah calon untuk presiden, senat atau kongres.

\section{Perubahan Perilaku}

Terdapat tiga proses perubahan perilaku yang dimulai dengan perubahan pengetahuan (kognitif) kemudian diikuti oleh perubahan sikap (afektif) dan yang terakhir adalah perubahan perilaku (psikomotor), ketiganya disingkat menjadi KAP. Juga dikenal sebagai fungsi domain perilaku KAP - B (Knowledge Attitude Practice - Behavior). Tokoh psikologi sosial Festinger (1957) mengemukakan tentang Cognitive Dissonance Theory. Dissonance terjadi karena dalam diri individu terdapat elemen kognisi yang saling bertentangan.

\section{Teori yang Relevan}

Banyak teori dikemukakan para ahli komunikasi, namun dalam penelitian ini menggunakan 1. Model proses informasi oleh Neisser, seperti yang dikutip oleh Achmad (1990:4) dalam bukunya Manusia dan Informasi.

\section{Gambar 1}

\section{Proses Terjadinya Informasi}

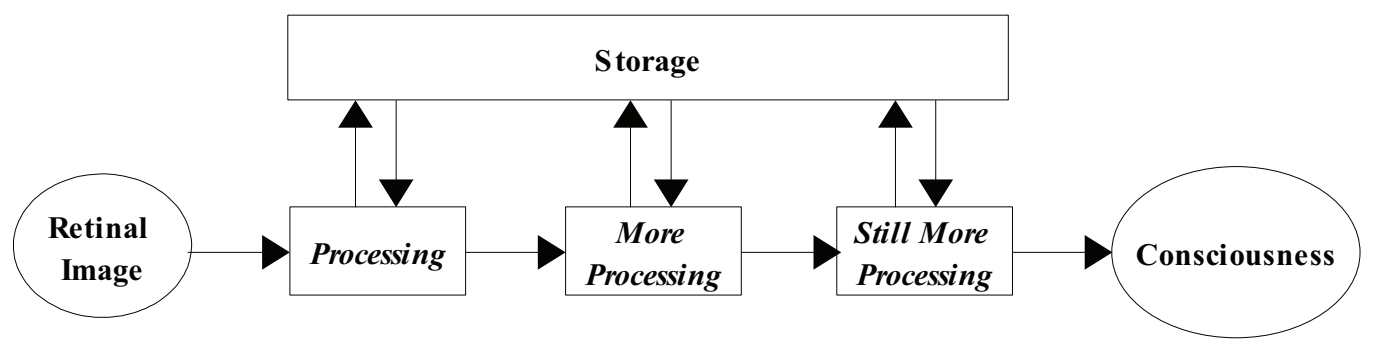

Sumber : A.S. Achmad, “Manusia dan Infromasi” (Achmad 1990:4) 
Model ini menggambarkan bagaimana proses informasi (stimuli) yang diterima (dalam bagan ini ditangkap oleh indera penglihatan), memasuki ambang kesadaran setelah melalui proses persenyawaan dengan informasi yang dipunyai (pengetahuan) yang tersimpan dalam gudang memori (storage) manusia atau khalayak yang dituju oleh informasi.

\section{Teori S-O-R (Stimulus - Organism - Response )}

Sebagai singkatan dari Stimulus Organism - Response, menurut stimulus respons ini, efek yang ditimbulkan adalah reaksi khusus terhadap stimulus khusus, sehingga seseorang dapat mengharapkan dan memperkirakan kesesuaian antara pesan dan reaksi komunikan yang jiwanya meliputi komponen-komponen : sikap, opini, perilaku, kognisi, afeksi, dan konasi. Jadi unsur-unsur dalam model ini adalah : 1. Pesan (Stimulus, S), 2. Komunikan (Organism, O) 3. Efek (Responsse, R). Dalam proses perubahan sikap yang dapat berubah hanya jika stimulus yang diterpa benar-benar melebihi semula.

Gambar 2 menunjukkan bahwa perubahan sikap bergantung pada proses yang terjadi pada individu. Stimulus atau pesan yang disampaikan kepada komunikan mungkin diterima atau mungkin ditolak, komunikasi akan berlangsung apabila ada perhatian dari komunikan. Proses berikutnya komunikan mengerti, kemampuan komunikan inilah yang melanjutkan pada proses berikutnya. Setelah komunikan mengolahnya dan menerimanya, maka terjadilah kesediaan untuk merubah sikap.

Gambar 2

Teori S-O-R

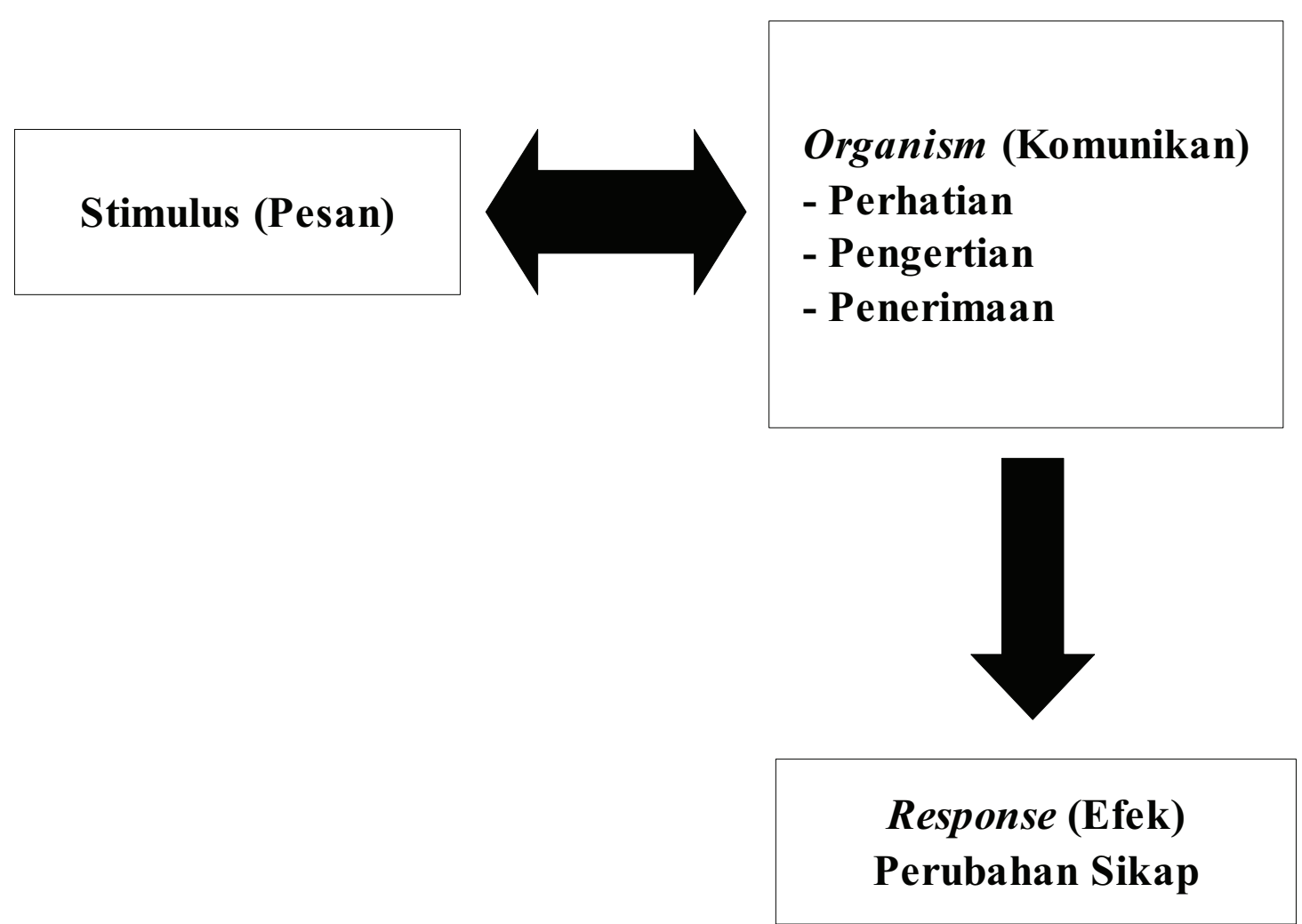


Gambar 3

Pendekatan DAGMAR (Defining Advertising Goals for Measured Advertising Results)

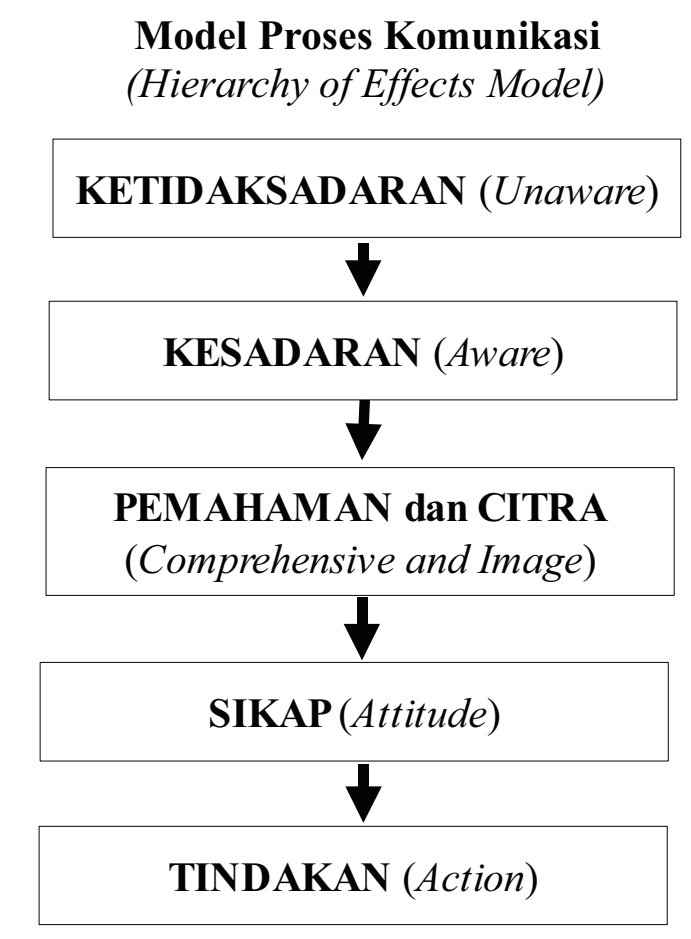

\section{Hipotesis}

Berdasarkan rumusan kerangka pikir tersebut, maka dapat dikemukakan hipotesis penelitian sebagai berikut:

- Ho : tidak ada pengaruh pesan politik caleg PKS melalui Short Message Service (SMS) terhadap sikap dan perilaku pemilih pada pemilu Legislatif Tahun 2009 di Kota Makassar

- Hi : Ada pengaruh pesan politik caleg PKS melalui Short Message Service (SMS) terhadap sikap dan perilaku pemilih pada pemilu Legislatif Tahun 2009 di Kota Makassar

\section{METODE PENELITIAN}

Jenis penelitian ini bersifat kuantitatif. Bentuk penelitian adalah survei, dan dilaksanakan pada tanggal 29 Juli sampai dengan 30 September 2009. Lokasi penelitian dilakukan di DPD PKS Kota Makassar.

Populasi dalam penelitian ini adalah seluruh caleg PKS yang terlibat langsung dalam pemilihan umum legislatif yang tersebar pada lima Dapil dengan jumlah pemilih di kota Makassar berdasarkan data dari Komisi Pemilihan Umum Daerah (KPUD) Makassar adalah sebanyak 795.702 pada Pemilu Legislatif 2009.

Teknik penarikan sampel yang digunakan dalam penelitian ini adalah Nonprobability sampel bertahap. Secara purposive memilih 5 Kecamatan dari 14 kecamatan di Kota Makassar yang mewakili masing-masing dapil, yaitu Kecamatan Rappocini mewakili Dapil I, Kecamatan Mariso mewakili Dapil II, Kecamatan Panakukang mewakili Dapil III, Kecamatan Wajo mewakili Dapil IV, dan Kecamatan Bringkanaya mewakili Dapil V, dengan jumlah sampel sebanyak 263 orang. Selain itu juga diadakan wawancara mendalam kepada 5 caleg PKS yang mewakili ke 5 lima) dapil tersebut.

Pada Penelitian ini terdiri dari dua variabel, yakni variabel bebas (Independent variabel) dan variabel terikat (Dependent variabel). Variabel bebas adalah pesan politik calon legislatif Partai keadilan Sejahtera 
(PKS) melalui SMS, sedangkan variabel terikat adalah pemilih pada pemilu legislatif 2009 di Kota Makassar.

\section{HASIL PENELITIAN DAN PEMBAHASAN}

\section{Bentuk Pesan Politik Caleg PKS Melalui Layanan Pesan singkat (SMS)}

Hasil penelitian menunjukkan bahwa bentuk penyusunan pesan politik caleg PKS melalui SMS terbagi atas 2(dua) yaitu (1) bentuk pesan bersifat informatif yakni untuk mengingatkan pemilih akan pelaksanaan Pemilu caleg 2009, sekaligus sosialisasi figur caleg PKS mengenai profil dan program caleg. Tentunya bentuk pesan ini diharapkan berpengaruh pada perubahan sikap, dan sebagai tujuan akhir adalah perubahan perilaku. (2) bentuk pesan (execution message) yang memakai teknik persuasi yaitu Fear appeal, Emotional appeal, Motivational appeal, Reward appeal, Humorious appeal. Dari hasil penelitian terdapat tiga, diantaranya yang diadopsi oleh caleg PKS dalam menyampaikan pesan politiknya yaitu emotional appeal, motivational appeal, dan humorious appeal, seperti di implementasikan oleh H.Muh Iqbal Djalil,Lc, sebagai berikut :

\begin{abstract}
“.........bentuk pesan politik caleg PKS lewat telpon seluler ataupun lewat SMS; 'Kita ada tim media yang khusus dirangkai oleh partai, ada juga per caleg. SMS partai untuk masyarakat secara umum, yakni : "Mengingatkan pemilu 2009 tanggal 09/04/2009 : Jangan Lupa Pemilu 09/04/2009 Pilih PKS No.8 Di Pojok Kanan Atas Partai Peduli, Bersih, Profesional“".(Wawancara; 24/8/09-17.00 Wita)
\end{abstract}

Dari penjelasan di atas dapat dimengerti bahwa caleg PKS yang memanfaatkan media SMS terbagi dua, yaitu melalui partai dengan fasilitas SMS centre dan pribadi. Untuk partai, bentuk SMS yang digunakan bersifat informatif yang bertujuan untuk memberikan informasi kepada pemilih tentang tanggal pencoblosan dan semboyan PKS yaitu bersih, peduli, dan professional.

Secara pribadi bentuk SMS yang digunakan oleh Muh. Iqbal Djalil adalah sebagai berikut :

“.........Aspirasi Anda adalah amanah bagi saya. Pilih yang berkualitas dan bermartabat,' (H.Muh.Iqbal,Lc, Caleg DPRD Kota Makassar, Dapil 5 Kecamatan Tamalate dan Biringkanaya). Dan biasanya saya tambahkan SMS seperti ini: Tolong sebarkan/ lanjutkan kalau Anda senang dengan saya. Terima kasih, semoga dengan ini Bapak/Ibu akan mendapat ganjaran dari Allah SWT. (Wawancara; 24/8/09-17.00 Wita)

Uraian di atas menjelaskan bahwa bentuk pesan yang dikemukakan tersebut ialah cara penyusunan pesan yang berusaha menggugah emosi khalayak, maka SMS yang digunakan oleh informan dapat dikategorikan sebagai bentuk pesan emosional appeal dengan mengungkapkan kata "Aspirasi dan Amanah" dan "berkualitas dan bermartabat". Selain itu informan juga menggunakan kata 'mendapat ganjaran dari Allah SWT' mengandung makna solidaritas sehingga mampu mengundang atensi publik dengan mengungkapkan masalah agama, dengan harapan masyarakat akan terbujuk dan menjatuhkan pilihannya kepada caleg tersebut secara emosi. Pesan yang dikembangkan oleh Iqbal memiliki daya tarik spiritual adalah yang berkaitan dengan makna dan nilai, yaitu untuk menempatkan perilaku dan hidup seseorang dalam konteks makna yang lebih luas dan kaya, untuk menilai bahwa tindakan atau jalan hidup seseorang mempunyai makna dibandingkan dengan orang lain.

Bentuk pesan yang sama dilakukan oleh Irwan (Caleg DPRD Kota Makassar, Dapil IV: Kecamatan Tallo, Ujung Tanah, Bontoala dan Wajo) sebagai berikut:

"sebagai salah satu partai yang bernuansa Islam, maka terkadang 
saya menulis SMS ke pemilih dengan nada-nada Islami atau bernuansa spiritual dengan tujuan untuk membangkitkan rasa solidaritas kita sebagai orang yang seiman. Misalnya 'jujur dan amanah adalah tekad saya jika dipercayakan sebagai wakil rakyat'. Mohon Doa dan Dukunganya'. Irwan, ST (Caleg DPRD Kota Makassar, Dapil IV: Kecamatan Tallo, Ujung Tanah, Bontoala dan Wajo (Wawancara; 27/8/09-17.00 Wita)

Uraian di atas menjelaskan, nilai-nilai spritual yang umum, yang dapat dikategorikan sebagai bentuk penyusunan pesan emosi (emotional appeal). Demikian halnya dengan strategi penyusunan pesan SMS yang dikembangkan oleh Muzakkir Ali Djamil (Caleg PKS Dapil I yang mewakili Kecamatan Rappocini, Makassar dan Ujungpandang). Hasil wawancara menjelaskan bahwa:

“........untuk orang yang saya anggap dekat dengan saya, isi pesannya lain dengan orang yang kenal biasa. Untuk orang dekat saya menggunakan kata-kata yang saya yakini menyentuh perasaannya, misalnya "kalau bukan kita siapa lagi, bantuka cappo, jujur dan berani berbuat untuk rakyat, bukan janji tapi bukti, bukan bicara tapi berbuat." diakhir SMS saya cantumkan kata Mohon doa dan Dukunganya Semua' (Muzakir Ali Djamil no urut 1 Caleg DPRD Kota Makassar, Dapil 1 Kecamatan Rappocini, Makassar dan Ujungpandang). PKS bersih dan Amanah. Sedangkan bagi orangorang yang secara umum isi SMSnya biasa saja, yaitu : No. Urut 1, Dapil 1 Kecamatan Rappocini, Makassar dan Ujungpandang. (Wawancara; 28/8/09-17.00 Wita).
Dari kutipan wawancara ini menjelaskan secara umum bentuk pesan politik caleg PKS melalui SMS yang digunakan di atas ada dua bentuk pesan yaitu emotional appeal dan motivational appeal. Yang dikategorikan sebagai bentuk pesan motivasi (motivational appeal) seperti dengan kata 'Jujur dan berani berbuat untuk rakyat, bukan janji tapi bukti, bukan bicara tapi berbuat'. Dalam konteks komunikasi politik, slogan-slogan yang dibuat oleh tim kampanye dapat digolongkan sebagai pesanpesan yang mengandung motivasi. Sedangkan bentuk pesan yang dikategorikan sebagai pesan emotional appeal adalah seperti kata'cappo' yang artinya berhubungan keluarga.

Oleh karena itu bentuk penyusunan pesan SMS seperti ini dapat dikategorikan sebagai pesan yang penuh dengan emosi atau emotional appeal.

Daya tarik emosional berhubungan dengan kebutuhan psikologis pemilih untuk memilih seorang caleg. Banyak pemilih termotivasi untuk mengambil keputusan dan memilih seorang caleg karena emosional dan perasaaan terhadap caleg dapat menjadi lebih penting daripada pengetahuan terhadap atribut dan pernik-pernik produk tersebut.

Berbeda dengan bentuk pesan politik caleg PKS yang dikemukakan oleh calegcaleg lainnya, Firman, Caleg DPRD Kota Makassar mewakili Dapil III Kecamatan Panakukang dan Manggala. Bentuk penyusunan politik yang berusaha membawa khalayak tidak merasa jenuh, yakni pesan yang disertai dengan humor., seperti dikemukakan berikut ini,

“... Kepercayaan adalah Amanah, Jangan kita Lupa Pilih dan Tandai" Firman, Bersih dan peduli. (Caleg DPRD Kota Makassar, Dapil III Kecamatan Panakukang dan Manggala). Kalau pilih yang lain dapat membuat BREKELE, tetapi Firman Gak Bikin BREKELE", Pesan politik melalui SMS ini disesuaikan dengan karakter pemilih yakni untuk pemilih pemula, dan orang yang sudah saya kenal sebelumnya."(wawancara : 07/09/2009) 
Kutipan wawancara di atas menjelaskan bahwa pesan disertai humor mudah diterima. Dalam praktik penjualan juga banyak dilakukan dalam bentuk humor. Produk sendiri bukan hanya terdiri dari dua jenis, barang (goods) ataupun jasa (service), namun dapat pula berupa ide, orang, organisasi, bahkan termasuk juga partai politik. Tiap-tiap jenis produk mempunyai cara pemasaran yang berbeda dan tak dapat disamakan strategi pemasarannya, begitu pun dengan bagaimana memasarkan pesan humor politik caleg Firman melalui SMS. Namun, bentuk pesan humor tersebut dilakukan untuk satu tujuan yang sama, yaitu memromosikan dirinya (yang bersangkutan), agar masyarakat dapat terbujuk untuk mengalihkan pilihannya pada caleg tersebut.

Secara keseluruhan bentuk SMS yang digunakan oleh informan di atas adalah mengadopsi ketiga bentuk penyusunan pesan; disatu sisi kata 'Kepercayaan adalah Amanah' dapat digolongkan dalam bentuk emotional appeal, kemudian kata "Janganki Lupa Pilih dan Tandai Firman, Bersih dan Peduli" dapat digolongkan sebagai pesan motivational appeal yang tampil dengan slogan.

Demikian halnya hasil wawancara terhadap caleg PKS lainnya yang lolos pada Pilcaleg 2009 Kota Makassar menunjukkan bahwa terdapat beragam strategi yang dikembangkan dalam hubungannya dengan mengolah pesan dan disalurkan dengan menggunakan media seluler atau SMS, seperti bentuk SMS yang dikemukakan $\mathrm{Hj}$. Sri Rahmi (Incumbent/ Caleg DPRD Kota Makassar, Davil II Kecamatan Mariso, Mamajang dan Tamalate). berikut ini :

Hasil wawancara tersebut di atas menjelaskan bahwa teknik penyusunan pesan yang dibuat bukan karena janji-janji, tetapi disusun untuk menumbuhkan pengaruh internal psikologis khalayak dengan ungkapan atau slogan "Bangkitnya Cahaya Hati kaum Perempuan, Jujur Dalam Pengabdian", mengandung pesan motivasi (motivational appeal).

Memang ada kecenderungan bahwa isuisu klasik yang selalu tampil dalam kampanye, yakni Para pejabat yang berkuasa (incumbent) cenderung menonjolkan prestasi yang telah dicapainya, sementara kandidat yang baru muncul biasanya menampilkan isuisu heroik misalnya perubahan (change) dan anti kemapanan.(Cangara, 2009 : 331).

Adapun maksud forward dari isi pesan di atas adalah melanjutkan pesan SMS tersebut ke nomor yang lain. Dengan demikian penyebaran pesannya sama dengan teknik pemasaran 'Multi Level Marketing' yang biasa digunakan dalam penjualan produk.

\section{Gambaran Pengetahuan, Sikap, dan Perilaku Pemilih dalam Pemilu Legislatif 2009 di Kota Makassar}

Sebelum dilakukan uji hipotesis, terlebih dahulu dijelaskan secara deskriptif tentang pengetahuan, sikap, dan perilaku pemilih dalam memahami SMS yang diterima dari caleg.

Berdasarkan hasil penelitian dapat dijelaskan bahwa dari 263 responden, terdapat 74 orang atau $28,14 \%$ yang mengenal Muzakir Ali, 70 orang atau 26,62\% yang mengenal Sri Rahmi, terdapat 44 orang atau $16,73 \%$ yang mengenal Firman, 56 orang atau $21,29 \%$ yang mengenal Iqbal, dan 19 orang atau $07,22 \%$ yang mengenal Irwan.

Sementara itu, terdapat 117 orang atau $44,49 \%$ yang menyatakan mengalami perubahan sikap dengan menyakini pesan caleg, 91 orang atau 34,60 \% yang menyatakan kurang setuju, dan 55 orang atau $20,91 \%$ yang menyatakan tidak setuju terhadap pesan caleg.

\section{Uji Hipotesis}

Pengaruh pesan-pesan politik calon legislatif Partai Keadilan Sejahtera (PKS) melalui SMS terhadap Sikap pemilih pada pemilu legislatif 2009 di Kota Makassar

Dari tabel 1 terlihat bahwa nilai t hitung lebih besar dari nilai t tabel. Dengan kondisi tersebut, atau kesimpulan yang dapat diambil adalah menolak Ho yang berarti koefisien pesan kampanye caleg melalui SMS dapat memrediksi sikap pemilih pada Pemilu 


\section{Legislatif 2009 di Kota Makassar.}

Pengaruh pesan-pesan politik calon legislatif Partai Keadilan Sejahtera (PKS) melalui SMS terhadap perilaku pemilih pada pemilu legislatif 2009 di Kota Makassar.

Dari tabel 2 terlihat bahwa nilai $\mathrm{t}$ hitung lebih besar dari nilai t tabel. Dengan kondisi tersebut, atau kesimpulan yang dapat diambil adalah menolak Ho yang berarti koefisien pesan kampanye caleg melalui SMS dapat memrediksi perilaku pemilih pada Pemilu Legislatif 2009 di Kota Makassar.

Tabel 1

\section{Output Analisis Regresi antara Pesan Caleg PKS Melalui SMS terhadap Sikap Pemilih}

ANOVA

\begin{tabular}{|l|c|c|c|c|c|}
\hline & $d f$ & $S S$ & $M S$ & $F$ & Significance F \\
\hline Regression & 1 & 23,94553 & 23,94553 & 4,518939 & 0,034461 \\
\hline Residual & 261 & 1383,02 & 5,298928 & & \\
\hline Total & 262 & 1406,966 & & & \\
\hline
\end{tabular}

\begin{tabular}{|l|r|r|r|r|r|r|}
\hline & Coefficients & Standard Error & \multicolumn{1}{c|}{ Stat } & P-value & Lower 95\% & Upper 95\% \\
\hline Intercept & 15,16829 & 0,867983 & 17,47532 & $8,25 \mathrm{E}-46$ & 13,45915 & 16,87743 \\
\hline X Variable 1 & 0,124058 & 0,058359 & 2,12578 & 0,034461 & 0,009144 & 0,238972 \\
\hline
\end{tabular}

Tabel 2

Output Analisis Regresi antara Pesan Caleg PKS Melalui SMS terhadap Perilaku Pemilih

\begin{tabular}{|c|c|c|c|c|c|}
\hline & $d f$ & $S S$ & $M S$ & $F$ & Significance F \\
\hline Regression & 1 & 29,94281 & 29,94281 & 5,67534 & 0,017922 \\
\hline Residual & 261 & 1377,023 & 5,27595 & & \\
\hline Total & 262 & 1406,966 & & & \\
\hline
\end{tabular}

\begin{tabular}{|l|r|r|r|r|r|r|}
\hline & Coefficients & Standard Error & \multicolumn{1}{c|}{ Stat } & P-value & Lower 95\% & Upper 95\% \\
\hline Intercept & 15,87868 & 0,788965 & 20,12596 & $5,05 \mathrm{E}-55$ & 14,32514 & 17,43223 \\
\hline X Variable 1 & 0,092846 & 0,064911 & 1,430355 & 0,153811 & $-0,03497$ & 0,220661 \\
\hline
\end{tabular}




\section{Bentuk Pesan Politik Melalui SMS}

Berbagai upaya dilakukan oleh para Caleg (Calon Legislatif) untuk memromosikan dirinya kepada masyarakat pemilih, hal ini ditujukan agar para caleg tersebut menang pada pemilu 2009 dan lolos menjadi calon legislatif yang notabene disebut juga sebagai wakil rakyat tersebut. Banyak cara untuk memromosikan diri si caleg tersebut, mulai dari spanduk-spanduk, brosur, di media cetak maupun iklan di siaran televisi nasional.

Namun semakin berkembangnya jaman, kampanye caleg tidak hanya dilakukan dengan cara demikian, sekarang ramai dibicarakan mengenai cara kampanye melalui SMS, yaitu mengampanyekan diri melalui pesan singkat yang dikirimkan ke masyarakat. Hal ini diakui oleh salah satu caleg yang lolos dalam putaran pemilu calon legislatif; $H$. Muh, Iqbal Djalil (caleg dari partai Keadilan Sejahtera) mengatakan bahwa dirinya rela mengeluarkan sejumlah uang (tanpa disebutkan jumlahnya) guna membeli "Software" pengirim pesan singkat ke banyak penerima, dalam pesan tersebut beliau mengampanyekan dirinya dengan sejumlah visi dan misinya kepada penerima tentunya dengan harapan agar pada pemilu Legislatif 2009 nanti ia bakal dipilih oleh penerima pesan tersebut, khususnya di daerah pemilihannya.

Dalam hubungannya dengan struktur pesan yang digunakan melalui media SMS, caleg Partai Keadilan Sejahtera (PKS) Kota Makassar telah melakukan beberapa upaya dalam usaha menarik minat pemilih. Misalnya dengan menggunakan penyusunan pesan informatif dan pesan persuasif dengan bentuk pesan memotivasi (motivational appeal), pesan emosional (emotional appeal), dan humor (humorious appeal). Meskipun masih terdapat bentuk pesan lain seperti pesan yang mengancam (fear appeal) dan pesan janji-janji (reward appeal) akan tetapi dari lima informan caleg PKS yang diwawancarai semua tidak menggunakan dua bentuk terakhir.

Hasil wawancara menunjukkan bahwa secara keseluruhan informan menggunakan bentuk pesan yang bersifat informatif dengan cara memberikan informasi kepada pemilih tentang tanggal dan waktu penyoblosan. Informasi ini bersifat umum karena hanya memublikasikan waktu penyoblosan. Selain pesan yang bersifat informatif, informan juga menggunakan bentuk persuasif dengan menggunakan tiga bentuk penyusunan pesan yaitu memotivasi (motivational appeal), pesan emosional (emotional appeal), dan humor (humorious appeal).

Dapat dikemukakan bahwa, model penyusunan pesan yang bersifat persuasif memiliki tujuan untuk mengubah persepsi, sikap dan pendapat khalayak. Sebab itu, penyusunan pesan persuasif memiliki sebuah proposisi. Proposisi disini ialah apa yang dikehendaki sumber terhadap penerima sebagai hasil pesan yang disampaikannya, artinya setiap pesan yang dibuat diinginkan adanya perubahan.

\section{Pengaruh Pesan Politik Melalui SMS Terhadap Sikap Pemilih}

Hasil penelitian menunjukkan menolak Ho yang berarti kontribusi variabel independen (pesan kampanye caleg melalui SMS) signifikan dalam memrediksi variabel dependen (sikap pemilih Kota Makassar). Persamaan regresi terlihat bahwa pada kolom Output Coefficient dimana nilai intercept sebesar 15,168 sedangkan Coefficient perilaku sebesar 0,124. Dengan demikian persamaan regresi adalah $\mathrm{Y}=15,168+$ $0,124 X$. Untuk menguji signifikansi persamaan regresi, kita dapat melihat pada nilai hitung masing-masing koefisien dan nilai $\mathrm{P}$ value. Dari hasil output terlihat bahwa nilai $\mathrm{t}$ hitung koefisien konstanta adalah sebesar 17,47 dengan nilai $\mathrm{P}$ sebesar 5,05. Jika kita bandingkan dengan nilai t tabel pada alpha $(5 \% / 2)=2,5 \%$ dengan $\mathrm{df}=(263-2=261)$ diperoleh nilai t tabel sebesar 0,677. Dari hasil tersebut terlihat bahwa nilai t hitung lebih besar dari nilai t tabel. Dengan kondisi tersebut, atau kesimpulan yang dapat diambil adalah menolak Ho yang berarti koefisien pesan kampanye caleg melalui SMS dapat memrediksi sikap pemilih pada Pemilu Legislatif 2009 di Kota Makassar.

Kategorisasi sikap responden bila diperhatikan perubahan sikap sebenarnya 
tidak terlalu banyak berarti karena secara kuantitas perubahan sikap responden yang didapatkan berdasarkan hasil perhitungan analisis regresi berada pada kisaran $0,14 \%$. Ini berarti bahwa terdapat $0,96 \%$ perubahan sikap responden dipengaruh oleh faktor lain.

Melalui wawancara dengan responden diketahui bahwa sikap informan terhadap pesan caleg melalui SMS cenderung menolak, sikap ini tentu saja didasari oleh penilaianpenilaian berdasar pada standar nilai tertentu. Keyakinan atau stigma masyarakat menjadi alasan sikap penolakan terhadap pesan caleg melalui SMS. Sikap kurang setuju terhadap pesan caleg melalui SMS pada informan lebih dikarenakan alasan-alasan etis, moral. Karena pada dasarnya norma masyarakat merupakan nilai yang ada dan dipercaya pada suatu kelompok masyarakat tertentu. Norma masyarakat berupa keyakinan umum yang berakar dari tradisi dan kepercayaan yang telah membudaya dan dijadikan pandangan masyarakat.

\section{Pengaruh Pesan Politik melalui SMS terhadap Perilaku}

Hasil penelitian menunjukkan menolak Ho yang berarti kontribusi variabel independen (pesan kampanye caleg melalui SMS) signifikan dalam memrediksi variabel dependen (perilaku pemilih Kota Makassar). Persamaan regresi terlihat bahwa pada kolom Output Coefficient dimana nilai intercept sebesar 15,878 sedangkan Coefficient perilaku sebesar 0,092. Dengan demikian persamaan regresi adalah $\mathrm{Y}=15,878+$ 0,092X. Untuk menguji signifikansi persamaan regresi, kita dapat melihat pada nilai hitung masing-masing koefisien dan nilai $\mathrm{P}$ value. Dari hasil output terlihat bahwa nilai $\mathrm{t}$ hitung koefisien konstanta adalah sebesar 20,125 dengan nilai $\mathrm{P}$ sebesar 5,05. Jika kita bandingkan dengan nilai t tabel pada alpha $(5 \% / 2)=2,5 \%$ dengan $\mathrm{df}=(263-2=$ 261) diperoleh nilai $t$ tabel sebesar 0,677 . Dari hasil tersebut terlihat bahwa nilai $t$ hitung lebih besar dari nilai t tabel. Dengan kondisi tersebut, atau kesimpulan yang dapat diambil adalah menolak Ho yang berarti koefisien pesan kampanye caleg melalui SMS dapat memrediksi perilaku pemilih pada Pemilu Legislatif 2009 di Kota Makassar.

Perubahan perilaku adalah perubahan yang terjadi dalam bentuk tindakan. Masyarakat yang semula tidak memilih dalam pemilu, akan berbalik menjadi pendukung setelah melihat kenyataan, bahwa caleg mampu (kompeten) bekerja dalam lapangan politik.

Keberhasilan proses komunikasi dengan menggunakan media SMS pada penelitian ini diukur melalui tingkat efektivitas SMS yang dinilai dari sejauhmana responden mampu memahami informasi caleg serta sejauhmana informasi tersebut dapat berpengaruh terhadap perilaku responden terkait dengan caleg. Dalam konteks ini komunikasi digunakan sebagai alat untuk memengaruhi sikap dan perilaku pemilih terkait dengan penentuan pilihan pada caleg yang memberikan informasi, atau dengan kata lain komunikasi digunakan sebagai alat propaganda.

Hal ini senada dengan apa yang diungkapkan Claude E. Shannon dan Warren Weaver dalam Mathematical Theory of Communication, bahwa efektivitas komunikasi dapat dihitung dan diukur secara matematis (akurasi transmisi pesan, ketepatan pesan terhadap makna, dan efektivitas pesan dalam mempengaruhi tindakan), sehingga komunikasi dapat dipakai sebagai alat kontrol. Karena pesan komunikasi dapat didesain dan diukur efektivitasnya, maka dalam perspektif propaganda komunikasi bisa digunakan sebagai alat manipulasi. Komunikasi dapat memengaruhi pola pikir dan membentuk nilai sesuai dengan apa yang diharapkan, dan dapat dijadikan alat penyampai pesan yang efektif guna mencapai tujuan tertentu sebagaimana diinginkan oleh pelaku komunikasi (Fikse, 1999). Dalam studi ini pengaruh antara pesan caleg PKS melalui SMS terhadap pemilih pada Pemilu Legislatif 2009 di Kota Makassar didapatkan bahwa terdapat relevansi antara faktor komunikasi dengan determinan perilaku (sikap dan perilaku).

Hasil wawancara menunjukkan bahwa 
informasi caleg yang diterima informan selama ini lebih banyak berasal dari media selain seluler seperti radio, koran, baligo, spanduk dan komunikasi personal lainnya. Bentuk komunikasi massa ini yang lebih bersifat informatif daripada edukatif. Namun bentuk komunikasi melalui seluler (SMS) ternyata juga memiliki peran terhadap pembentukan perilaku pemilih terkait dengan penentuan pilihan pemilih pada caleg tertentu.

\section{KESIMPULAN}

Bentuk pesan politik SMS terhadap pemilih dalam pemilu legislatif 2009 di kota Makassar dikelompokkan dalam dua bentuk pesan, yaitu: (a) bentuk informatif, dan (b) pesan yang persuasif. Bahwa pada dasarnya pemanfaatan SMS sebagai media penyampai pesan politik caleg PKS adalah memperkenalkan dan mengingatkan caleg tersebut kepada masyarakat agar masyarakat dapat terbujuk untuk mengalihkan perhatiannya pada caleg tersebut.

Hasil analisis pengaruh pesan politik melalui SMS terhadap sikap pemilih, menunjukkan, ada pengaruh antara pesan politik melalui SMS terhadap sikap dan perilaku pemilih dalam pemilu legislatif 2009 di Kota Makassar. Pesan politik melalui SMS sifatnya efektif, murah, dan memenuhi kriteria komunikasi massa, yaitu dilaksanakan oleh sebuah institusi, ada unsur keserempakan dan disebarkan ke masyarakat luas. Namun, dalam pesan politik caleg PKS melalui SMS ada unsur-unsur yang harus diperhatikan dalam pengelolaannya, karena jika tidak, maka hal tersebut dapat mengaburkan pesan yang justru ingin disampaikan. Dalam SMS, titik, koma, singkatan-singkatan, simbolsimbol jika pengelolaannya tidak tepat, dapat mengaburkan isi pesan. Tetapi jika dikelola dengan baik dan segmented, maka bisa menjadi kekuatan yang luar biasa.

Efektivitas pesan politik melalui SMS karena menyentuh orang perorang. Orang yang menerima pesan politik melalui SMS dapat membacanya berulang-ulang atau bahkan mengirimkan ke teman-temannya. Namun hiruk pikuknya pesan politik jenis ini dikhawatirkan memunculkan black campaign (kampanye hitam) alias ajang fitnah kepada lawan politik. Karena itu perlu ada aturan yang jelas terhadap pelaksanaan penggunaan SMS sebagai media penyampaian pesan politik Caleg kepada konstituen.

\section{DAFTAR PUSTAKA}

Achmad, A.S., 1990. Manusia dan Informasi. Makassar : Lembaga Penerbitan UNHAS .

Bulaeng, Andi. 2000. Metodologi Penelitian Kontemporer. Makassar : Lembaga Penerbitan UNHAS .
---------------. 2002. Teori dan Manajemen
Riset Komunikasi. Jakarta : Narendra.

Cangara, Hafied. 2007. Pengantar Ilmu Komunikasi. Edisi Revisi. Jakarta : Raja Grafindo Persada. 2009. Komunikasi Politik Konsep, Teori, dan Strategi. Jakarta : PT. Rajagrafindo Persada.

DeFleur, M.L. 1975. Theories of Mass Communication (2 nd Edition). New York :Davic Mc Kay Company.

Effendi, Onong Uchjana, 1992. Ilmu Komunikasi dalam Teori dan Praktek. Bandung: Remaja Rosdakarya .

Graber, Doris A. 1984. Media Power in Politics. Washington, D.C : Printed in the Uniteds States of America .

Kriyantono, 2007. Metode Penelitian Komunikasi. Bandung : Remaja Rosdakarya .

McQuail, Denis. 1994. Teori Komunikasi Massa, Edisi Terjemahan, Dharma, Agus dan Ram, Amiruddin. Jakarta : Erlangga.

Mulyana, Deddy. 1999. Nuansa-nuansa Komunikasi Meneropong Politik dan Budaya Komunikasi Masyarakat Kontemporer. Bandung : PT Remaja Rosdakarya .

Nimmo, Dan. 1999. Komunikasi Politik (Komunikator, Pesan dan Media). Terjemahan oleh Tjun Surjaman, 1989. Bandung : Remaja Karya. 2001. Komunikasi Politik: 
Khalayak dan Efek. Terjemahan oleh Tjun Surjaman. 1989. Bandung : Remaja Rosdakarya.

Program Pascasarjana Universitas Hasanuddin, 2003. Pedoman Penulisan Tesis dan Disertasi. Makassar .

Rakhmat, Jalaluddin. 2001. Metode Penelitian Komunikasi. Cet. Ketujuh. Bandung : PT. Remaja Rosdakarya . 1996. Psikologi Komunikasi. Bandung : PT Remaja Rosdakarya

Rodee, dkk. 2000. Pengantar Ilmu Politik. Jakarta : PT RajaGrafindo Persada .

Roger, Everett. 1986. Communication Technology. The New media of Society. New York: The Free Press.

Singarimbun, Masri \& Effendi, Sofian. 1989. Metode Penelitian Survai. Jakarta : LP3ES .

Siregar, Ashadi. 1990. Komunikasi Sosial. Yogyakarta : Badan Penelitian dan Pengembangan Fisipol UGM .

Sudibyo, Agus. 2001. Politik Media dan Pertarungan Wacana. Yogyakarta : LkiS.

Sugiyono. 2003. Statistika Untuk Penelitian. Bandung: Alfabeta

Sulastri, Irta. 2001. Pengaruh Berita dan
Artikel Politik dalam Surat Kabar terhadap Partisipasi Politik Mahasiswa di Kota Padang (Studi Aksi Mahasiswa Terhadap Usulan Pencabutan TAP. MPRS. No. XXV Tahun 1966). Tesis tidak diterbitkan. Bandung : Program Pascasarjana Universitas Padjadjaran.

Surbakti, Ramlan, 1984. Dasar-dasar Ilmu Politik. Surabaya : Airlangga University Press.

Susanto, Astrid. 1988. Komunikasi dalam Teori dan Praktek I. Bandung : Binacipta.

\section{Sumber lainnya :}

\section{Internet :}

http://id.wikipedia.org/wiki/politik diakses : 24/02/2009).

http://www.total.or.id/info.php?

$\mathrm{kk}=$ information\%20technology- diakses : 02/02/2009 